\title{
TRIAL BY JURY AND THE NEW FEDERAL RULES OF PROCEDURE FLEMING JAMES, JR. $\dagger$
}

Fourteen years ago the Supreme Court said:

"Section 274b [of the Judicial Code]" is an important step toward a consolidation of the federal courts of law and equity, and the questions presented in this union are to be solved much as they have been under the state codes. . . . The most important limitation upon a federal union of the two kinds of remedies in one form of action is the requirement of the Constitution in the Seventh Amendment. . . ."2

Today the last step in this consolidation is imminent. ${ }^{3}$ Before it is taken we may properly examine the solutions found by the states for the similar problems raised under their codes. For throughout this country, just as in the British Empire, there has been a wealth of experience under a united procedure which should indeed point some morals to guide future codifiers.

The constitutional guaranty of jury trial must first be studied, for it circumscribes all that may be said and done. We shall next discuss what can be accomplished under a union of law and equity. Two questions will then arise: whether the codes have in any measure failed to attain these ends; and, if they have, what are the causes of failure. Analysis of the causes may indicate the manner in which the pitfalls can be avoided.

\section{The Constitutional Guaranty of Jury Trial}

Virtually all code states guarantee in their constitutions the right of trial by jury. ${ }^{4}$ The provisions are almost monotonous in their essential similarity, though there are various different qualifications on the right, not here material..$^{5}$ Some expressly state that the right may be waived; ${ }^{\circ}$

$\dagger$ Associate Professor of Law, Yale University; formerly Research Assistant to the Supreme Court's Advisory Committee on Rules for Civil Procedure.

1. 38 StaT. 956 (1915), 28 U. S. C. A. $\$ 398$ (1926). This permitted equitablo defenses to be interposed to actions at law.

2. Taft, C. J., in Liberty Oil Co. v. Condon Nat. Bank, 260 U. S. 235, 242 (1922).

3. 48 STAT. 1064,28 U. S. C. A. $\$ \$ 723$ b, 724c (1934); See Clark and Moore, $A$ Ncw Federal Civil Procedure, II. Pleadings and Parties (1935) 44 YALE L. J. 1291.

4. Colorado and Louisiana have no constitutional guaranty of jury trial in civil actlons. Coso. Const. art. II, § 23; Huston v. Wadsworth, 5 Colo. 213 (1880); LA. Const. art. I, \& 9.

5. The Connecticut provision is a model of brevity: "The right of trial by jury shall remain inviolate." Cons. CoNST. art. I, § 21. Substantially this wording is found in all such sections. Many also contain provisions for a jury of less than twelve, or a verdict by less than all. These have no present bearing.

6. ArIz Const. art. II $\S 23$; Ark. Const. art. II, $\& 7$; CAx. Const. art. I, $\S 7$; MnNN. Const. art. I, $\S 4$, among others, have such express provision for waiver. 
most do not. There is great uniformity, also, in the decisions outlining the extent of the right. What was guaranteed was only the preservation of that mode of trial where it existed at common law.? The chancellor did not submit to a jury issues over which he took jurisdiction, except as a matter of discretion. And where a "civil action" presents such issues today these constitutions do not compel their submission to a jury. ${ }^{8}$ The test is purely historical; new proceedings and actions for the enforcement of statutory rights being either beyond the scope of the guaranty or treated by way of analogy as within its scope. ${ }^{0}$

The situation under the federal Constitution is no different. ${ }^{10}$ The Seventh Amendment" ". . . correctly interpreted, cannot be made to em. brace the established exclusive jurisdiction of courts of equity, nor that which they have exercised as concurrent with courts of law; but should be understood as limited to rights and remedies peculiarly legal in their nature, and such as it was proper to assert in courts of law, and by the appropriate modes and proceedings of courts of law."12 Where history affords no exact precedent historical analogy is invoked. ${ }^{13}$ Thus proceedings for condemnation under the power of eminent domain, ${ }^{14}$ and proceedings to enforce forfeitures ${ }^{15}$ (except in admiralty) are triable by a

7. There is an occasional decision that the right preserved was that which existed when the Constitution was adopted. Usually, it would make no difference which test was applisd, but it may be important. Thus when Arizona adopted her Constitution, a statute [Ariz Rev. Stat. (1901) $\S 1389$ ] was in force which gave to either party a right to bave all cases, legal or equitable, submitted to a jury. It was held that the Constitution, therefore, gave a right to jury trial in equity cases. Brown v. Greer, 16 Ariz. 215, 141 Pac. 841 (1914). This decision has been overruled, however. Donahue v. Babbit, 26 Ariz. 42, 227 Pac. 995 (1924); Miller v. Thompson, 26 Ariz. 603, 229 Pac. 696 (1924). And various Mfiszouri constitutions have been deemed to sanction the preexisting local practice of compelling a reference in a suit at law which presented complicated accounts. Shepart v. Banls of Afiz:ouri, 15 Mo. 143 (1851); Edwardson v. Garnhart, 56 MTo. 81 (1874); Creve Coeur Lalie Ice Co. v. Tamm, 138 Mo. 385,39 S. W. 791 (1897).

8. Davis v. First Nat. Bank, 26 Ariz. 621, 229 Pac. 391 (1924); Mieriden Sav. Bank v. McCormack, 79 Conn. 260, 64 A. 338 (1906); Kimball v. Connor, 3 Kan. 414 (1866); Brown v. Heller, 30 N. MI. 1, 227 Pac. 594 (1924). These cases are merely representative.

9. Gregory v. Hecke, 73 Cal. App. 268, 238 Pac. 787 (1925); Ex parte Liggett, 187 Cal. 428, 202 Pac. 660 (1921) ; Flaherty v. MIurphy, 291 IIl. 595, 126 N. E. 553 (1920); Anderson v. Caldwell, 91 Ind. 451 (1883); Kimball v. Connor, 3 Kan. 414 (1866); Hawley v. Wallace, 137 Minn. 183, 163 N. W. 127 (1917); State v. Kelly, 57 IIont. 123, 187 N. W. 637 (1920).

10. See Capital Traction Co. v. Hof, 174 U. S. 1, 23 (1899).

11. Which reads: "In suits at common lav, where the value in controversy shall exceed twenty dollars, the right of trial by jury shall be preserved. ..."

12. Shields v. Thomas, 59 U. S. 253,262 (1855).

13. The leading case is Parsons v. Bedford, 28 U. S. 433 (1830), which aroze under the law of Louisiana, assumed to be "peculiar."

14. Beatty v. United States, 203 F. 620 (C. C. A. 4th, 1913); cf. Kohl v. United States, 91 U. S. 367 (1876); Chappell v. United States, 160 U. S. 499 (1896).

15. The Sarah, 21 U. S. 391 (1823); United States v. One Hundred \& Thirty Barrels 
jury, while a statutory suit to cancel a naturalization certificate for fraud is not. ${ }^{16}$

When $\S 274 \mathrm{~b}$ of the Judicial Code permitted the interposition of equitable defenses in actions at law the constitutional problem as to mode of trial was solved in this way:.

"Where an equitable defense is interposed to a suit at law, the equitable issue raised should first be disposed of as in a court of equity, and then, if an issue at law remains, it is triable to a jury. ... The equitable defense makes the issues equitable, and it is to be tried to the judge as a chancellor. The right of trial by jury is preserved exactly as it was at common law. The same order is preserved as under the system of separate courts. If a defendant at law had an equitable defense, he resorted to a bill in equity to enjoin the suit at law, until he could make his equitable defense effective by a hearing before the chancellor. The hearing on that bill was before the chancellor, and not before a jury, and, if the prayer of the bill was granted, the injunction against the suit at law was made perpetual, and no jury trial ensued. If the injunction was denied, the suit at law proceeded to verdict and judgment. This was the practice in the courts of law and chancery in England when our Constitution and the Seventh Amendment were adopted, and it is in the light of such practice that the Seventh Amendment is to be construed." 17

One other aspect of the constitutional right deserves attention, namely, that reasonable regulations and restrictions may be placed upon it. Thus a party may be compelled to make an affirmative claim of his right to jury trial, by prescribed conduct, on pain of being held to waive it. ${ }^{18}$ And this is true without regard to whether the Constitution expressly provides for waiver ${ }^{19}$ except that such express mention may have a restrictive effect as in California where it is construed to limit methods of waiver to

of Whisky, 1 Bond 587, 27 Fed. Cas. No. 15983, p. 281 (S. D. Ohio 1865); United States v. The Queen, 4 Ben. 237,27 Fed. Cas. No. 16107 , p. 669 (S. D. N. Y. 1870); aff'd, 11 Blatchf. 416, 27 Fed. Cas. No. 16108 , p. 672 (C. C. N. Y. 1873); ef. Wickwire v. Reinecke, 275 U. S. 101 (1927); Meeker v. Lehigh V. Rr. Co., 162 F. 354 (S. D. N. Y. 1908). 16. Luria v. United States, 231 U. S. 9 (1913); cf. Esterly v. Rua, 122 F. 609 (C. C. A. 9th, 1903).

17. Liberty Oil Co. v. Condon Nat. Bank, 260 U. S. 235, 242, 243 (1922).

18. Jenkins v. Skelton, 21 Ariz. 663, 192 Pac. 249 (1920); Bennett v. Hillman, 37 Cal, App. 586, 174 Pac. 362 (1918); McKay v. Fair Haven \& W. Rr. Co., 75 Conn. 608, 54 Atl. 923 (1903); Kainea v. Kreuger, 30 Haw. 860 (1929); Sutton v. Gunn, 86 Ga. 652, 12 S. E. 979 (1891); Heard v. Kennedy, 116 Ga. 36, 42 S. E. 509 (1902); Foster v. Morse, 132 Mass. 354 (1882); State ex rel. Clark v. Neterer, 33 Wash. 535, 74 Pac. 668 (1903). The constitutionality of such a rule was at least questioned in Brown v. Greer, 16 Ariz. 222, 141 Pac. 843 (1914). But the question was put at rest in Jenkins v. Skelton, supra.

19. Cf. cases cited supra note 18 , with constitutional provisions cited sttpra note 6 . Two constitutions provide that there shall be a waiver of jury right unless it is affirmatively claimed. Micr. Const. art. II, \& 13; UTAR Const. art. I, \& 10. Such provisions dilfer from those in the constitutions cited supra note 6 , in that the latter are merely permissive. 
those indicated by the legislature. ${ }^{20}$ Another type of regulation commonly upheld is the requirement of a jury fee, prepayment of which is made a condition precedent to the enjoyment of the right."2

"The Constitution does not guarantee to the citizen the right to litigate without expense, but simply protects him from the imposition of such terms as unreasonably and injuriously interfere with his right to a remedy in the law, or impede the due administration of justice.":ㅡㄹ

There are cases to the contrary, and no doubt there are limits which cannot be passed. ${ }^{23}$ But it seems fairly clear that a reasonable jury fee may be imposed, under the Federal as well as State Constitutions.."

\section{The Objectives of a United Procedure}

We begin by stating what are believed to be the objectives of a united procedure. Appraisal of the extent to which the various codes are designed to achieve these objectives will follow.

1. Litigants should be enabled and compelled to pursue in a single suit all their claims and defenses, and obtain all the remedies to which they are entitled, with respect to a single occurrence. ${ }^{25}$ Moreover there should be no lingering prohibition against joinder of causes of action or

20. Exline v. Smith, 5 Cal. 112 (1855) (words "prescribed by law" as used in this section mean prescribed by act of the legislature); Biggs v. Lloyd, 70 Cal. 447, 11 Pac. 831 (18s6); People v. Metropolitan Surety Co., 164 Cal. 174, 128 Pac. 324 (1912).

21. Conneau v. Geis, 73 Cal. 176, 14 Pac. 580 (1Ss7); Bank of Lassen v. Sherer County, 108 Cal. 513, 41 Pac. 415 (1S95); Williams v. Gottschalk, 231 III. 175, 83 N. E. 141 (1907); Adams v. Corriston, 7 Minn. 456 (1862); State ex rel. Clark v. Neterer, 33 Wach. 535, 74 Pac. 668 (1903). Cases are collected in (1924) 32 A. L. R. 865. Cf. Beers v. Beers, 4 Conn. 535 (1S23); Flint River Steamboat Co. v. Foster, 5 Ga. 194 (1S48).

22. Adams v. Corriston, 7 Minn. 456 (1862).

23. See (1924) 32 A. I. R. 865 , at 869 . In Labome v. Balthazor, 180 Wis. 419,193 N. W. 244 (1923), a \$24 jury fee in a municipal court having a civil jurisdiction not to exceed \$̦1000 was held unreasonable and unconstitutional.

24. Venine v. Archibald, 3 Colo. 163 (1877) is a direct bolding under the Seventh Amendment (\$\$20 fee in Territorial court held valid). Adsms v. Corriston, 7 Minn. 456 (1862), is such a holding by implication, since the State Constitution contains but a continuation of the jury trial right enjoyed under the United States Constitution in the Minnesota Territory. St. Paul \& S. C. Rr. Co. v. Gardner, 19 Minn. 132 (1872). In Capitol Traction Co. v. Hof, 174 U. S. 1 (1899), many of the early cases cited here were reviewed and approved. The court held that an act enlarging the civil juricdiction of Justices of the Peace, beyond disputes involving more than $\$ 20$ did not by reacon of lacl: of provision for jury trial, violate the Seventh Amendment, so long as a jury trinl on appeal to the Supreme Court of the District of Columbia was provided. And ". . . the right of trial by jury ... is not unduly obstructed by the provisions ... requiring every applicant to give security to pay and satisfy the judgment of the appellate court." 174 U. S. 1, 45 (1899).

25. That the parties should be enabled to pursue and obtain all such rights and remedies in a single suit seems so clearly to be one of the aims of a united procedure that it needs no discussion. That they should be compelled to do so (if they are enabled) seems to be no more than a logical application of the salutary rule against splitting a cause of action. Cf. note 29 , infra. 
interposition of counterclaims because some are "legal," others "equitable."

2. The right of jury trial should not be expanded. This method of settling disputes is expensive and dilatory ${ }^{20}$-perhaps anachronistic. ${ }^{27}$ Indeed the number of jury trials should be cut down if this can be done so as not to jeopardize the attainment of the other objectives.

3. The union of law and equity should be fashioned to yield a system that works well administratively and raises a minimum of questions as to its operation. The latter of course necessitates a strict regard for the constitutional limitation in devising the framework of the union.

\section{To What Extent Have These Aims Failed of Attainment?}

Some of these objectives have been widely accomplished under various systems uniting law and equity. Almost everywhere, for instance, a plaintiff may claim both legal and equitable relief arising from a single cause of action. ${ }^{28}$ There is some question as to whether he must unite such claims, on pain of waiving those not included, but the prevailing code rule apparently requires him to do so. ${ }^{20}$ Further, parties may generally join legal and equitable causes of action ${ }^{30}$ and interpose legal counterclaims in equitable actions $\mathrm{s}^{31}$ and equitable counterclaims and defenses in actions claiming only legal relief. ${ }^{32}$

One of the greatest difficulties seems to be associated with what may be termed a "theory of the pleadings" doctrine. In the few states where it is accepted, this doctrine may be invoked either at the pleading or trial stage of the case. It defeats a litigant if he has failed either to allege,

26. GREEN, JUdGe AND JURX (1930) c. 15; Clark and Shulman, Jury Trial in Civil Cases-A Study in Judicial Administration (1934) 43 YaLE L. J. 867; Corbin, The Jury on Trial (1928) 14 A. B. A. J. 507; Wigmore, A Program for the Trial of Jutry Trial (1929) 12 Aar. Jod. Soc. Journ. 166; Elder, Trial by Jury: Is it Passing? (1928) 156 Harper's 570. These are only a few of the recent comments on these aspects of jury trial. 'Thoy cite many others.

27. See articles cited supra note 26; Duane, Civil Jury Should be Abolished (1929) 12 Axr. JUd. SOC. JourN. 137.

28. Cases collected in Clark, Code Pleading (1928) 302, n. 33 ; 313, n. 83.

29. Serrao v. Noel, 15 Q. B. D. 549 (Ct. App. 1885); Royal Ins. Co. v. Stewart, 190 Ind. 444, 129 N. E. 853 (1921); Naugle v. Naugle, 89 Kan. 622, 132 Pac. 164 (1913); Gilbert v. Boak Fish Co., 86 Minn. 365, 90 N. W. 767 (1902); Waldo v. Lockard, 101 Neb. 797, 165 N. W. 154 (1917); Inderlied v. Whaley, 85 Hun. 63, 32 N. Y. Supp. 640 (1895); Habl v. Sugo, 169 N. Y. 109,62 N. E. 135 (1901) ; Brice v. Starr, 90 Wash. 369, 156 Pac. 12 (1916). It has been said that such a result is repudiated by the weight of authority. Note (1922) 22 Cor. L. Rev. 180; (1921) 14 A. L. R. 5, 543. But theso statements, as is shown by the cases cited in their support, fail to take into account the effect of the codes. See, for example, Perdue v. Ward, 88 W. Va. 371, 106 S. E. 874, 14 A. L. R. 543 (1921); Ciark, Code Pleading (1928) 321, 322.

30. Clark, Code Pleadng (1928) 301, 302. 31. Cases cited infra notes 70 and 71.

32. Clark, Code Pleading (1928) \& 96. 
or to prove, all the facts necessary to support the legal theory on which his pleading is found to have been drawn. ${ }^{33}$ It is of no consequence that the facts pleaded, or proved, may entitle him to relief under some other theory; nor does it matter that there is no variance between the facts proved and the allegation of the complaint.

One line of cases arises on demurrer to the complaint. They hold that where only equitable relief is demanded the complaint is defective if its allegations do not show that plaintiff is entitled to such relief, even though the facts pleaded may show that he is entitled to damages. ${ }^{\text {I }}$ In New York these decisions are expressly grounded on $\$ 479$ of the Civil Practice Act. $^{35}$ In Missouri the analogous statute is differently framed, ${ }^{36}$ but the same result flows from a fear of jeopardizing the right to jury trial. ${ }^{37}$

As we have seen the theory of the pleadings doctrine may be invoked at the trial. A rather striking example of this is seen in the case of Magwire v. Tyler. 38 This was a suit "in the nature of a bill in equity" praying for possession of land, an accounting and other relief. The pleadings traced out title in detail. Plaintiff's theory was that he had the "better equity."30

33. Our concern here is with this doctrine as it is applied to perpetuate the distinction between law and equity. It is perhaps somewhat more widely used to keep alive the old forms of action. The famous Indiana cases are mostly of the latter bind. Oolitic Stone Co. v. Ridge, 169 Ind. 639, 83 N. E. 246 (1908) ; see Crask, Code Pleabric (1928) 174-179, and cases cited; Albertsworth, Theory of the Plesdings in Code States (1922) 10 Chrm. L. REv. 202. The trend in New York is outlined in Whittier, The Theory of a Pleading (1908) 8 Cor. L. Rev. 523.

34. Rush v. Brown, 101 Mo. 5\$6, 14 S. W. 735 (1890); Planet Property \& F. Co. v. St. L. O. H. \& C. Rr. Co., 115 Mo. 613, 22 S. W. 616 (1893); State ex rel. Hibbs v. IfcGee, 328 Mo. 1176, 44 S. W. (2d) 36 (1931); Low v. Swartwout, 171 App. Div. 725, 157 N. Y. Supp. 1067 (1st Dep't, 1916); Spring v. Fidelity Mut. L. Ins. Co., 183 App. Div. 134, 170 N. Y. Supp. 253 (3d Dep't, 1918); and cases cited in Crark, Code Prernaic (1928) 182, n. 156.

35. "Where there is no answer, the judgment shall not be more favorable to the plaintifi than that demanded in the complaint. Where there is an answer, the court may permit the plaintiff to take any judgment consistent with the case made by the complaint and embraced within the issue." That such a provision is usual, see CLinE, Code Plesonic (1928) 180, 181. The cases here referred to construe this word "answer" so as not to include demurrer. See also Buena Vista F. \& V. Co. v. Puohy, 107 Cal. 243, 40 Pac. 386 (1895). Judicial construction of this section is not always so narrow. Crars, loc. cit. supro. Those cases cited infra note 45 , which involve the ruling on a demurrer, do not mention this section.

36. Mo. Stat. Awn. (Vernon, 1932) \$ 1050 authorizes the court to grant "any relicf consistent with the case made .. . and embraced within the issues" except where an "interlocutory judgment" is rendered under $\S 1073$ in the absence of defendant's "answer or other pleading."

37. Rush v. Brown, 101 Mo. 586, 13 S. W. 735 (1890); Humphreys v. Atlantic Milling Co., 98 Mo. 542, 10 S. W. 140 (1888).

38. 47 Mo. 115 (1870).

39. See Magwire v. Tyler, 40 MIo. 406, 433 (1867). 
The trial court gave him judgment. The state supreme court reversed this judgment on the ground that defendant had legal and equitable title. The case was appealed to the United States Supreme Court, federal land patents being involved. There the ruling of the state supreme court was reversed on the ground that plaintiff had legal title. ${ }^{40}$ Motion was then made in the present proceedings before the state supreme court to affirm the trial court's judgment. But the trial court's judgment was reversed instead and the petition dismissed, on the ground that the United States Supreme Court had decided only the federal question, and its decision showed that plaintiff had a legal remedy-ejectment-so that his bill stated no cause for equitable relief. The court talked the language of a common law system. Apparently its chief concern was the right to jury trial. ${ }^{41}$ The classic case on this issue is Jackson $v$. Strong. ${ }^{42}$ Plaintiff sued defendant alleging what was in effect a partnership and asking for an accounting and recovery of the amount due. Defendant answered by a general denial and allegations that the contract was not one of partnership but of employment. The action was tried to a referee who found that defendant's version was correct and awarded plaintiff the reasonable value of his services, as the contract called for. In reversing the judgment, the Court of Appeals said:

"We have then a case wherein the complaint sets forth a cause of action in equity which, as the finding was, the plaintiff failed to prove on the trial, and the court without any amendment of the pleadings awarded the plaintiff damages as in an action at law. Was that proper? I think not. There is some confusion in the cases bearing upon this subject, but the weight of authority is that, where some ground of equitable jurisdiction is alleged in a complaint, but fails of proof in its entire scope on the trial, and it appears that there never was any substantial cause for equitable interference, the court will not retain the action and grant purely legal relief, but will dismiss the complaint. .. . The inherent and fundamental difference between actions at law and suits in equity cannot be ignored. As has often been said: . . . 'Pleadings and a distinct issue are essential to every system of jurisprudence, and there can be no orderly administration of justice without them. If a party can allege one cause of action and then recover upon another, his complaint would serve no useful purpose.'"

In spite of this language the court ordered, not a dismissal of the complaint, but a new trial. ${ }^{43}$ Nothing is said in the case about jury trial, but

40. Maguire v. Tyler, 75 U. S. 650 (1869).

41. See $47 \mathrm{Mo}$. at 126-128. Other comparable Missouri cases are McKee v. Allen, 204 Mo. 655, 103 S. W. 77 (1907); Fowles v. Bentley, 135 Mo. App. 417, 115 S. W. 1090 (1909). But cf. Bragg v. Specialty Shoe Mach. Co., 225 Mo. App. 902, 34 S. W. (2d) 184 (1931).

42. 222 N. Y. 149,118 N. E. 512 (1917). A very similar decision is Anderson v. Chilson, 8 S. D. 64,65 N. W. 435 (1895).

43. The language was taken at its face value, however, and the complaint ordered dismissed in a similar situation by the Appellate Division. Poth v. Washington Square M. E. Church, 207 App. Div. 219, 201 N. Y. Supp. 776 (1st Dep't, 1923). 
fear of depriving defendant of his right to it seems to lurk behind the reasoning and the rescript. Certainly that is the interpretation put on the case by commentators. ${ }^{44}$

These decisions are not followed in the majority of code states ${ }^{45}$ or in England. ${ }^{46}$ Clearly, then, they are not necessary consequences of a united procedure. Insofar as they are a product of the typical American statutory pattern ${ }^{47}$ they are attributable to only two of its aspects; viz; (1) the provision limiting the relief to that demanded "where there is no answer, ${ }^{\prime 48}$ and (2) defects in the provisions governing the mode of trial. These are the points to which attention must be directed if such results are to be avoided. ${ }^{49}$ No real danger to the constitutional right of jury trial lurks in a union of law and equity. But the existence of fears on this ground $d^{50}$ is largely responsible for the difficulty we are dealing with, and indicates the necessity of drafting the rules in such a way as to mark plainly a method which will at once safeguard all legitimate rights, yet allow a full enjoyment of the benefits of abolishing the old distinctions.

The theory of the pleadings doctrine is not the only bette noir of the codes. There are cases extending the right to jury trial beyond the re-

44. See Clark, Code Pleadnig (1928) 69, 70; Albertsworth, Theory of the Pleadings in Code States (1922) 10 CalrF. L. Rev. 202, 206; Clark, The Union of Law and Eqtity (1925) 25 Cor. L. Rev. 1; Scott, The Progress of the Law 1918-1919, Civil Procedure (1919) 33 Harv. L. REv. 236, 240; Comment (1923) 22 YaLE L. J. 707; Note (1918) 32 Harn.

L. REv. 166; (1918) is Cor. L. REv. 281.

45. Gambrell v. McKean, 28 Ariz. 427, 237 Pac. 196 (1925); Murphey v. Brown, 12 Ariz. 268, 100 Pac. 801 (1909); White v. Lyons, 42 Cal. 279 (1571); Jaeckel v. Pease, 6 Idaho 131, 53 Pac. 399 (1898); Bonnell v. Allen, 53 Ind. 130 (1876); Thomas v. Farley Mifg. Co., 76 Iowa 735, 39 N. W. 874 (1S88); Canty v. Lattemer, 31 Minn. 239, 17 N. W. 385 (18s3); Greenieaf v. Egan, 30 Minn. 316, 15 N. W. 254 (18s3); Cassidy v. Slcmons \& Booth, 41 Mont. 426, 109 Pac. 976 (1919); Security Nat. Bank v. Geck, 96 Obla. 39, 220 Pac. 373 (1923); Damon v. Leque, 14 Wash. 253, 44 Pac. 261 (1896); Leonard v. Rogan, 20 Wis. 540 (1866).

46. Bannatyne v. MacIver, [1906] 1 K. B. 103 (C. A.).

47. The typical code formula is somewhat different from that found in the Englich Supreme Court of Judicature Act and its prototypes. The former declares the abolition of the distinctions between law and equity and provides that there shall be but one form of civil action. The example par excellence, of course, is the provision of the original Field code. N. Y. Sess. Laws 1848 , c. 379, $\$ 62$. No such declaration appears in any of the British acts. These ordinarily coutain a direction to the court to administer both law and equity in the same case according to preseribed rules, and vest the court with appropriate power to do so. See, for example, 15 and 16 Gro. V, c. 49, $\S \S 18,36$ (1925); Arnersa REv. Stat. (1922), cap. 72, $\$ \S 14,15,37$; Australia, Judictarr ACT of 1903-1927, $\delta \S 31$, 32; ONtario Rev. Stat. (1927) c. $88, \S \S 2,15$.

48. See supra note 35 . It would be so easy to draft a rule which would preclude the undesirable construction that this point will not again be mentioned.

49. Indeed it might well be a step backward for the federal courts to adopt rules involving such results as these. See Clarksburg Trust Co. v. Comm. Cas. Ins. Co. 40 F. (2d) 626 (C. C. A. 4th, 1930).

50. See supra notes 37,41 , and 44 . 
quirements of the constitution. ${ }^{51}$ There are cases depriving a party of a jury trial because he has joined legal and equitable claims or interposed a legal counterclaim to an equitable action. ${ }^{.2}$ There are situations incompatible with administrative efficiency and productive of unnecessary litigation. ${ }^{53}$ How these results come about, why they tend to defeat the objectives of a united procedure (where that is not obvious), and how they have been avoided in some states, are questions to be discussed in the course of the article.

\section{The Code Provisions Governing the Mode of Trial}

Before turning to a study and comparison of the various statutory attempts to solve the problem of form of trial, it may be well to take note of the different kinds of situations in which it is presented under the codes. There are today many suits which are, from summons to judgment, no more than the counterpart of the former action at law. The typical personal injury case furnishes a ready example. Other suits present throughout only such facts and claims as would clearly have been cognizable in equity. Foreclosure actions, at least where the amount of the debt is admitted, give a pertinent illustration. These are "civil actions," to be sure, but they offer no difficulty peculiar to a system where law and equity are blended. Such difficulty is most obviously presented by a proceeding wherein facts are stated and remedies sought which must have required at least two actions before the code, one at law and the other in equity. The case may be one where a plaintiff unites legal and equitable claims, or where an equitable defense or counterclaim is interposed to an action presenting only legal issues or vice versa. The most striking aspect of such an action, for present purposes, is that it has no counterpart at common law. It is patent that if the whole action is to be treated as a unit in determining the problem of mode of trial either one or two things will happen: matters historically equitable will be tried by a jury or matters historically legal will be tried by a court. ${ }^{\text {.4 }}$ In order to come at the units dealt with by the common law and by the constitutions, it is necessary to break down the kind of action supposed into its component issues and to see which of them would have been disposed of by the chancellor, and which he would have relegated to the law court with its trial by jury. ${ }^{55}$

51. See infra notes 75 and 89 .

53. See, e.g., infra notes 125, 126, 135, 139.

52. See infra notes $65,70,71$, and 87 .

54. By a "jury" is meant a common law jury. Trial to a court would include, of course, trial to the "advisory" jury countenanced in equity.

55. It would not be the other way round, because when the chancellor assumed jurisdiction over a cause he would settle all issues of which he took cognizance, whether or not they were such as were also cognizable in a law court. So in the sort of situntion wo have postulated only those issues which the chancellor would not dispose of would actually 


\section{The New York Provision}

As a part of the original New York Code, it was provided:

"Whenever, in an action for the recovery of money only, or of specific real or personal property, there shall be an issue of fact, it must be tried by a jury, unless a jury trial be waived, as provided in section 221 , or a reference be ordered, as provided in sections 225 and 226."

This provision was widely copied by the other code states, the principal exceptions being separately treated below. Whatever variations exist among statutes of this type are of little significance. These most important aspects they all have in common: (1) they designate the "action" as the unit to be dealt with; and (2) they assume to describe and enumerate the actions triable to a jury without any express reference to the historical, or pre-code, criteria for determining when that kind of trial was to be had. ${ }^{\text {57 }}$

Where the civil action is the recognizable equivalent of either a law action or a suit in equity, this type of statute has given little difficulty and has received fairly uniform construction: "This provision is no broader than the provision of the Constitution." ${ }^{268}$ So where a plaintiff seeks money only but avers facts under which no money judgment could formerly have been had until after an accounting in equity, he is not entitled to a jury. ${ }^{59}$ Nor is he where he tries to get possession of specific property by compelling performance of a contract to sell it. ${ }^{c 0}$ And if the right to money or the possession of property depends upon any right, title,

have been tried to the jury at common law. This is too familiar law to call for citation, but the opinion in the Liberty Oil case, supra note 2, spells it out clearly.

56. N. Y. SESS. Laws, 1848, c. 379, \& 208. The present New York section reads: "In each of the following actions an issue of fact must be tricd by a jury unlesa a jury trial is waived or a reference is directed: 1 . An action in which the complaint demands judgment for a sum of money only. 2. An action of ejectment; for dower; for wacte; for a nuisance; or to recover a chattel." N. Y. C. P. A. (1920) $\S 425$.

57. E.g., Cal. Code Crv. Proc. (Deering, 1931) \& 592; Coro. Code Crv. Proc. Amzi.

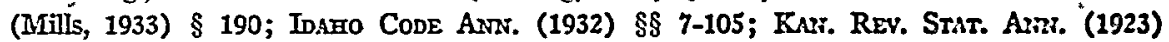
$\S \S 60-2903$; MinN. Star. (MIason, 1927) § 9288; Mo. Star. Arw. (Vernon, 1932) 8943. The English statute also enumerates kinds of actions in which a jury trial shall be had; but the problem is entirely different in England where there is no constitutional guaranty of jury trial. 23 and 24 GEo. V. c. $36, \S 6$ (1933).

58. Morton Brick \& T. Co. v. Sodergren, 130 Minn. 252, 153 N. W. 527 (1915).

59. United Coal Co. v. Canon City Coal Co., 24 Colo. 116, 48 Pac. 1045 (1897); Morton v. Morton Realty Co., 41 Idaho 729, 241 Pac. 1014 (1925); Minch v. Winters, 122 Kan. 533, 253 Pac. 578 (1927); Bond v. Welcome, 61 Mlinn. 43, 63 N. W. 3 (1895); Morton Brick \& T. Co. v. Sodergren, 130 Minn. 252, 153 N. W. 527 (1915); Ely v. Coontz, 167 Mo. 371, 67 S. W. 299 (1902).

60. Davis v. Judson, 159 Cal. 121, 113 Pac. 147 (1910); Schaeffer v. United Banli and Tr. Co., 104 CaI. App. 635, 286 Pac. 723 (1930); Plains Iron Worles Co. v. Hnggott, 72 Colo. 228, 210 Pac. 696 (1922); Brady v. Yost, 6 Idaho 273, 55 Pac. 542 (1893); Hamilton v. Hamilton, 59 Mo. 232 (1875). 
or interest which only equity would recognize at common law, a jury is generally denied ${ }^{61}$ though these actions seem to fit within the literal statutory description of cases triable to a jury. Likewise foreclosure suits are treated as actions neither for the possession of property nor for the recovery of money. ${ }^{62}$ No criticism is made of the statutes' operation in these cases. It results in giving a jury trial where the constitution demands it, and not elsewhere. The wording of these statutes, however, does not seem to be a very apt expression of constitutional interpretation, though it may not be misleading.

How then does this type of provision work when it is confronted by an action presenting both legal and equitable aspects-the peculiar product of the codes? In this situation there is far less unanimity among the cases. Some courts have relatively little trouble with the statutory language.

"In actions, originally actions at law, either party may demand a jury trial. In actions which, according to the former practice, were equitable action ... ., neither party can demand a jury trial as of right. ... In mixed actions ... the legal issues are triable by a jury and the equitable issues by the court."

Thus the issue is taken as the unit wherever the civil action comprises more than any action could before the code. This technique is very frequently adopted under these statutes though it seems to do violence to their language. ${ }^{64}$ But the expression in the provision is sometimes taken more literally. So where a plaintiff unites what would have been a common law action for a nuisance with a claim for equitable relief, he has been held to forego his right to jury trial. What results from such union is no longer an "action for a nuisance" within the code. 65 True the parties had a constitutional right to jury trial of those issues which the common

61. Cree v. Lewis, 49 Colo. 186, 112 Pac. 326 (1910) ("True, plaintiff demanded and was given a money judgment, but this relief depended upon the establishment of a trust."); Ross v. Ross, 139 Kan. 316, 31 P. (2d) 718 (1934); Conran v. Sellew, 28 Mo. 320 (1859) ("These provisions manifestly make a distinction between suits which were formerly recognized as actions at law, and bills in equity; and the mode of trial in a given caso under the present code may generally be determined by ascertaining whether under tho old system it would be cognizable at law or in equity.").

62. Proctor v. Arakelian, 208 Cal. 82, 280 Pac. 368 (1929); Danielson v، Gude, 11 Colo. 87, 17 Pac. 283 (1888); Christensen v. Hollingsworth, 6 Idaho 87, 53 Pac. 211 (1898); Robertson v. Moore, 10 Idaho, 115, 77 Pac. 218 (1904); Sawyer v. Ryan, 141 Kan. 368, 41 Pac. (2d) 740 (1935).

63. Morton Brick \& T. Co. v. Sodergren, 130 Minn. 252, 254, 153 N. W. 527, 528 (1915). But contrast Johnson Service Co. v. Kruse, 121 Minn. 28, 140 N. W. 118 (1913).

64. See cases infra notes 69,73 , and 74 .

65. Cogswell v. New York, N. H., \& H. Rr. Co., 105 N. Y. 319, 11 N. E. 518 (1887). The code provision referred to is now N. Y. C. P. A. (1920) $\S 425$. 
law suit comprised, but the plaintiff (though not the defendant ${ }^{20}$ ) has waived his right by joining the two claims. ${ }^{67}$ This case was not decided on the ground that the chancellor would formerly have taken cognizance of all the issues and settled them without the intervention of a jury. ${ }^{63}$ The reasoning of the opinion makes it clear that the statutory right is narrower than the constitutional right. ${ }^{\text {99 }}$

The mode of trial of legal issues injected by a counterclaim into a suit theretofore "equitable" has been similarly treated." In fact, under provisions of the New York type, the defendant is probably generally held to waive jury trial of such issues by thus interposing them. ${ }^{\pi 1}$ This results from regarding the action as the unit for treatment, as the statute prescribes.

Equitable issues introduced by way of defense or counterclaim have caused perhaps the most serious difficulty. At the outset a distinction should be drawn between "equitable" matter formerly pleadable at law, and matter which could be remedied before the codes, only by a suit in

66. Hudson v. Caryl, 44 N. Y. 553 (1871), cited for this proposition in the Cogsurell case. Cf. City of Syracuse v. Hogan, 234 N. Y. 457, 138 N. E. 406 (1923).

67. According to this case he need not have joined them. But cf. cases, stspro note 29.

68. Whether or not the holding could be esplained on this ground [cf. dissenting opinion of Cardozo, J., in City of Syracuse v. Hogan, 234 N. Y. 457, 138 N. E. 406 (1923) ], the reasoning cannot be. See Morton Brick \& T. Co. v. Sodergren, 130 Minn. 252, 255, 153 N. W. 52S, 529 (citing Cogswell case).

69. For cases not in accord with this result, see Moore v. San Vicente L. Co., 175 Cal. 212, 165 Pac. 687 (1917); Hughes v. Dunlap, 91 Cal. 385, 27 Pac 642 (1891) ("each remedy must be governed by the same law that would apply to it if the other remedy had not also been asked for."); Bradley v. Parkhurst, 20 Kan. 462 (1878); MrHoney v. German Ins. Co., 44 Mo. App. 426 (1891); Austin v. Brooliyn Cooperage Co., 285 S. W. 1015 (Mo. App. 1926).

70. Johnson v. Niichels, 48 Idaho, 654, 284 Pac. 840 (1930); Dover Lumber Co. v. Case, 31 Idaho 276, 170 Pac. $10 S$ (1918); Ryman v. Lynch, 76 Iowa 587, 41 N. W. 320 (1889); Fisher v. Rakestraw, 117 Kan. 441, 232 Pac. 605 (1925); Johnson Service Co. v. Kruse, 121 Minn. 28, 140 N. W. 118 (1913); Johnson v. Peterson, 90 Mrinn. 503, 97 N. W. 384 (1903). But cf. Sandstrom v. Smith, 12 Idaho 446, 86 Pac. 416 (1906).

As in the situation where a plaintiff joins legal and equitable claims, the constitutional difficulty here is surmounted by treating the voluntary interposition of such a counterclaim as a waiver of jury right. Johnson Service Co. v. Kruse, sttpra. No doubt plaintifi could insist on a jury. See Sandstrom v. Smith, supra; Perfection T. \& R. Co. v. Kellogs Mackay Eq. Co., 194 Iowa 523, 187 N. W. 32 (1922). Some of the cases could scarcely have been decided otherwise under any statute, for the "legal counterchim" presented no more than defendant's version of the same facts which plaintiff relied on. Such a situation is admirably analyzed in Reichert v. Krass, 13 Ind. App. 348, 40 N. E. 706, 41 N. E. 835 (1895). Cf. Larkin v. Wilson, 28 Kan. 513 (18s2).

71. A good collection of cases is found in (1934) 89 A. L. R. 1391, which malies this statement: "The great weight of authority is to the effect that the interposition by the defendant in an equitable action, of a counterclaim of a legal nature, gives him no right to a jury trial, either of the case generally or of the issue raised by the counterchim." Cases from Kentucky (dealt with below) are distinguished on the ground that the statute in that state is different. 
equity affirmative in form. The former is "equitable" merely by reason of its remote origin, but it has long been assimilated to the law and triable as other legal issues were; it presents no problem peculiar to code pleading. ${ }^{79}$ We shall not again refer to it as equitable. The other matter-that which required a suit in chancery-was never triable as of right by a jury. A simple example will serve to illustrate the procedure. Alleging legal title in himself, Plaintiff brings an action of ejectment against Defendant, who is in possession of the land. Defendant's possession is under an oral contract for the sale of the land, and he claims to have improved it. These facts are not available as a defense to ejectment, so Defendant brings a separate suit in equity and gets a temporary injunction against the prosecution of the law action. The chancellor determines the questions made by the bill and answer. If he finds for Defendant (plaintiff in the equitable action), he enters the appropriate decree disposing of all the issues presented and perpetually staying the law action. No jury trial at all has been had. If on the other hand, the chancellor finds against Defendant, he dismisses the bill and Plaintiff is free to prosecute his action at law with a jury trial of whatever issues remain (e.g. the value of rent and profits). This marks the extent of the constitutional right to jury trial in such a case. The situation is changed at least to this extent by the codes: There need be no more than one action in which all of Plaintiff's and Defendant's claims may be presented and adjudicated. But the constitutional right is not altered and even under statutes of the New York type, such as that of California, the problem of mode of trial is capable of a similar solution.
"The equitable and legal matter should be kept distinct and separate, else confusion, embarrassments, and delays must ensue. We laid down the proper mode of proceeding in the case of Argullo v. Edinger (10 Cal. 159 [1858]). 'The defense arising from a verbal contract for the sale of land ... is permissible, under our system of practice, to an action of ejectment for the recovery of the premises. The only effect of this mode of asserting the rights of the defendants, instead of by a bill in equity, is to require the court to pass upon the questions raised by the answer in the first instance. If upon hearing the evidence, the court should determine there was ground for relief, it would enjoin the further prosecution of the action with its decree for a specific performance; and on the other hand, if it should refuse the relief, it would call a jury to determine the issue upon a general denial.' " 73

Nor is this method of solving the difficulty unusual. ${ }^{74}$ But the statute

72. See the exposition in Cook, Equitable Defenses (1923) 32 YaxE L. J. 645; cf Hinton, Equitable Defenses Under Modern Codes (1920) 18 Mrcr. L. R. 717.

73. Weber v. Marshall, 19 Cal. 447, 457 (1861). Compare the essentially similar technique adopted by the Supreme Court in Liberty Oil Co. v. Condon Nat. Bank, 260 U. S. 235 (1922).

74. Sooy v. Cerf, 220 Cal. 611, 32 P. (2d) 365 (1934); Stwasey v. Adair, 88 Cal. 179, 25 Pac. 1119 (1891); Fish v. Benson, 71 Cal. 428, 12 Pac. 454 (1886); Bodley v. Frrguson 
has been held to require trial of the whole action to the jury, unless the answer sets forth matter which requires affirmative relief for the complete protection of the defendant. ${ }^{75}$ And since it often-perhaps usually -does not, ${ }^{76}$ this rule operates greatly to enlarge the scope of jury trials. These decisions depend not upon "constitutional privilege, but . . . the meaning of legislation. The federal courts have found it possible in construing the provisions of the Judicial Code . . . to reserve to the judge the trial of equitable defenses while leaving the legal issues to the verdict of the jury."777

The New York type of provision, then, has some tendency to emphasize the action as the unit for treatment in determining the jury trial question. This, in turn, leads to a tendency to extend the scope of jury trial in some situations, and restrict it in others. These results, it is submitted, should be avoided if possible. We have mentioned the serious

30 Cal. 511 (1863); Davis v. Holbrook, 25 Colo. 493, 55 Pac. 730 (1898); Jenks v. Lchman, 7 Colo. App. 421, 43 Pac. 1045 (1896); Penningar Lateral Co. Ltd. v. Clark, 22 Idaho 397, 126 Pac. 524 (1912); Williams v. Howes, 137 Minn. 462, 162 N. W. 1049 (1917); Crosby v. Scott-Graff L. Co., 93 Minn. 475, 101 N. W. 610 (1904).

75. This view is most clearly set forth in Susequehanna S. S. Co. v. A. O. Anderson \& Co., 239 N. Y. 285, 146 N. E. 381 (1925), noted in (1925) 25 Cor. L. REv. 630; (1926) 11 Conn. L. Q. 396; cf. Clark, Trial of Actions Under the Code (1926) 11 Cons. L. Q. 482,490 . In Missouri a long line of decisions has declared that where an equitable defense is interposed to a complaint tendering only legal issues, all issues are triable to a jury (at least on plaintiff's insistence) unless the defendant has prayed for affirmative equitable relief. "The courts have established a working theory for such procedure by treating a suit at law in which an equitable defense is interposed, accompanied by a prayer for affirmative equitable relief, as a case in equity, triable to a chancellor." Shaffer v. Detie, 191 Mro. 377, $90 \mathrm{~S}$. W. 131 (1905). On the whole the distinction seems to turn on mere form. Thus in an action for the possession of land where the defendant pleaded laches and equitable estoppel, without asking for relief, a jury trial of all issues was held proper. Toler v. Edwards, 249 Mo. 152, 155 S. W. 26 (1913). And the court distinguished another case where the answer was said to be "identical," except that it sought complete reliaf, on this ground alone. Withers v. Kansas C. S. B. Rr. Co., 226 MFo. 373, 126 S. W. 432 (1910). Another striking example of the importance attached to form is sen in Carter v. Metropolitan Life Ins. Co., 275 Mo. 84, 204 S. W. 399 (1913), where a defense of fraud in the factum was directed to be tried to the court alone because concellation of the policy was demanded, and this "changed the action at law into one in equity." On the other hand, an affirmative prayer which would accomplish nothing more for the defendant than a simple judgment in his favor has been held an insufficient basis for taling equitable issues from the jury. Chilton v. Chilton, 297 S. W. 457 (BIo. 1927); Thompson v. National Bank of Commerce, 132 Mo. App. 225, 110 S. W. 681 (1908). But this analysis is scarcely compatible with the result in other cases. Shaffer v. Detie, sttfra, Carter v. Mretropolitan Ins. Co., supra; Hughes v. Community Bank of Dawn, 7S S. W. (2d) 98 (Mo. 1934). So the test seems not only to enlarge the scope of jury trial but also to be an undesirably uncertain one in practice.

76. This is true of the illustration given above in the text, borrowed from Weber $v$. Marshall, 19 Cal. 447 (1861). It is also true of many of the cases cited supra note 74. 77. Cardozo, J., in the Susquehanna case, 239 N. Y. 285, 146 N. E. 381 (1925). 
criticism levelled at the jury system. ${ }^{78}$ At any rate its extension to issues hitherto withheld from it-because they are, under salutary compulsion, tendered in defense to a legal claim-would appear to be a questionable policy. Many of these issues have been safeguarded from juries by rules of the common law representing centuries of experience, and whatever wisdom it possessed. ${ }^{79}$ But these considerations do not make it desirable to deny a party's right to jury trial of legal issues which he has injected into a suit otherwise of equitable cognizance. In the first place this probably may not be done constitutionally; ${ }^{80}$ it certainly cannot be as to any legal issues which the new Rules may compel to be interposed. And if it may be done to any extent, it would discourage parties from putting forward such claims as they wish to have tried to a jury, thus defeating, pro tanto, the aim to avoid multiple actions.

\section{The Indiana provision}

The Indiana statute provides:

"Causes triable by court and by jury. Issues of law and issues of fact in causes that prior to the 18th day of June, 1852, were of exclusive equitable jurisdiction shall be tried by the court; issues of fact in all other causes shall be triable as the same are now triable. In case of the joinder of causes of action or defenses which, prior to said date, were of exclusive equitable jurisdiction with causes of action or defenses which, prior to said date, were designated as actions at law and triable by jury-the former shall be triable by the court, and the latter by a jury, unless waived; the trial of both may be at the same time or at different times, as the court may direct: Provided, That in all cases triable by the court as above directed, the court, in its discretion, for its information, may cause any question of fact to be tried by a jury, or the court may refer any such cause to a master commissioner for hearing and report."181

This provision substitutes the word "causes" for the more usual "actions," and expresses what has been inferred from other statutes: that the same causes shall be tried to the court now as before the code. ${ }^{82}$ Under it a plaintiff may unite legal and equitable claims and causes of action without any fear of waiving his jury trial right, ${ }^{83}$ except in a situation

78. See supra notes 26 and 27.

79. As, for example, the parol evidence rule.

80. Cf. American Mills Co. v. American Surety Co., 260 U. S. 360 (1922); Tilton v. Horton, 103 Fla. 497, 137 So. 801 (1931); Blanton v. Woodward, 107 Fla. 691, 144 So. 300 (1932). But cf. cases supra note 70.

81. Ind. Stat. ANN. (Burns, 1933) § 437.

82. The results seem to be the same. There is no right to trial by jury of an action to foreclose a lien [Tomlinson v. Bainaka, 163 Ind. 112, 70 N. E. 155 (1904)]; of an action for an accounting and the amount found due [McBride v. Stradley, 103 Ind. 465, 2 N. E. 358 (1885); cf. Hendricks v. Frank, 86 Ind. 278 (1882)]; of an action for the possession of realty to which plaintiff claims equitable title. Carpenter v. Willard Library Trustees, 26 Ind. App. 619, 60 N. E. 365 (1900).

83. Field v. Brown, 146 Ind. 293,45 N. E. 464 (1896); cf. Hartlep v. Murphy, 197 
where the chancellor would haye determined the legal issues, historically. ${ }^{84}$ This result has been made easier because of the wording of the provision. The same is true of equitable defenses. A recent case presented a situation essentially like that raised under the New York code in the Szusquehanno case ${ }^{75}$ but the procedure deemed impossible in the latter case was followed and approved in Indiana; the issues raised by the answer being tried first to the court, the remaining issues to a jury. ${ }^{85}$ But the Indiana statute has given trouble in a different quarter, and for precisely the same reason that the New York Act does. Whatever was intended, the statute in words makes issues triable one way or the other if they are raised "in causes" which were, or were not, as the case may be, of exclusive equitable jurisdiction before the code. Now "causes" has been taken as synonomous with "suits," ${ }^{\text {" }}$ and it was no great step from this to conclude that: "A part of the relief sought by the complaint was such as prior to June 18th, 1852, could be granted only in a court of equity. Under Section 409, R. S. 1881 [present $\S 437$ ] such causes must be tried by the court." Similar reasoning in another type of suit has led to the opposite extreme. The Indiana statutory action to quiet title is available to a plaintiff in possession or out of possession of the land in dispute. It includes what was ejectment as well as the old equitable bills of peace and quia timet, but is broader than any or all of them. An early decision very properly held that a plaintiff out of possession had a right to jury trial of such an action since his suit presented only issues which would

Ind. 222, 150 N. E. 312 (1926); Rich v. Fry, 196 Ind. 303, 146 N. E. 393 (1925); Watt v. Barnes, 41 Ind. App. 466,84 N. E. 158 (1908).

84. Carmichael v. Adams, 91 Ind. 526 (1883); Hendricks v. Frank, 86 Ind. 278 (1832). The opinion in Field v. Brown, 146 Ind. 293, 45 N. E. 464 (1896), clearly points out the distinction.

85. Piggly-Wiggly Stores v. Lowenstein, 197 Ind. 62, 147 N. E. 771 (1925). Both cases involved a suit for damages for breach of a written contract, and an answer setting up mutual mistake and asking for reformation of the writing. Afirmative relief scems to have been no more necessary in one than the other. Cf. also Supreme Tribe of Ben Hur v. Bastian, 85 Ind. App. 327,151 N. E. 346 (1926); Lindley v. Sullivan, 133 Ind. 58s, 32 N. E. 738, 33 N. E. 361 (1892) where the same method was assumed to be proper, but defendant was held to have waived his right to a court trial of the equitable issues by not asking for it. In Peden v. Cavins, 134 Ind. 494, 34 N. E. 7 (1893), the plaintiff was held to have waived jury trial by claiming it of all issues, including those raised by the equitable defense. In the Bastian case supra, "affirmative reliel" was clearly unnecessary; it may have been in the others also.

S6. Hendricks v. Frank, 86 Ind. 278 (1882).

87. Lake v. Lake, 99 Ind. 339, 342 (1884). To the same effect is Towns v. Smith, 115 Ind. 480,16 N. E. 811 (1888) ("if any essential part of the cause is exclusively of equitable cognizance, the whole is drawn into equity"). This reproduced the situation in New York under Cogswell v. New York, N. H. \& H. Rr. Co., 105 N. Y. 319, 11 N. E. 518 (1887). It has been pointed out that such reasoning was hater repudiated. See sufro note 83. It stands nevertheless as a warning of the pitfalls inherent in the statutory language. 
formerly have been raised in ejectment. ${ }^{88}$. The next year this case was twice cited as holding that all issues in any action to quiet title were triable to the jury, and the view was expressed that since the statutory action was broader than the old equity suits it was not a cause exclusively within the jurisdiction of equity before 1852 , and was therefore triable to a jury by reason of the jury trial statute. ${ }^{80}$ Thus, the word "causes" in section 437 is taken to refer not so much to any particular suit as a unit as to a whole class of suits made and labelled with a very different purpose in mind. This result is not reached even under the California (New York type) statute. ${ }^{90}$

\section{The Kentucky provision}

The type of provision next considered is to be found in those states which have not a complete amalgamation of law and equity, yet which are commonly classed as code states: Arkansas, Iowa, Kentucky, and Oregon. The Kentucky Code is sufficiently like the others that we may take it as our example. Under it there shall be but one form of action, though actions are ordinary or equitable. ${ }^{91}$ Actions over which courts of chancery had jurisdiction before 1851 may be equitable, and actions of which such jurisdiction was exclusive must be equitable, all other actions must be ordinary. ${ }^{92}$ Error as to the form of action is not abatable but only cause for change to the proper docket and amendment, if necessary. ${ }^{03}$ The plaintiff may correct such error before answer or later by leave of

88. Trittipo v. Morgan, 99 Ind. 269 (1884).

89. Johnson v. Taylor, 106 Ind. 89, 5 N. E. 732 (1886); Kitts v. Wilson, 106 Ind. 147,5 N. E. 400 (1886). A more rational view was taken in Martin v. Martin, 118 Ind. 227, 20 N. E. 763 (1889), only to be repudiated in Puterbaugh v. Putcrbaugh, 131 Ind. 288, 30 N. E. 519 (1892), which reaffirmed the earlier rule. Curiously enough, the technique for determining the extent of the constitutional right to jury trial seems almost to reverse this process. Anderson v. Caldwell, 91 Ind. 451 (1883).

90. The latter is of the familiar New York type, sttpra notes 56 and 57. Donahue v. Meister, 88 Cal. 121, 25 Pac. 1096 (1891); Angus v. Craven, 132 Cal. 691, 64 Pac. 1091 (1901); Davis v. Judson, 159 Cal. 122, 113 Pac. 147 (1910). In these cases a distinction is drawn between those "actions to quiet title" which would formerly have been equitable, and those which would have been legal. Cf. Standard Co. v. Young, 90 Conn, 133, 96 Atl. 932 (1916).

91. Ky. Codes Ans. (Carroll, 1927) Civ. prac., $\$ \S 4$, 5; Iowa Code (1935) $\$ 10940$; ARK. Drg. Stat. (Crawford and Moses, 1919) $\$ \S 1030,1031$, 1033. The Oregon statutes give much less detailed directions. ORE. CODE ANN. (1930) $\S \S 6-101,6-102$. Formerly a complaint was dismissed if brought on the wrong side of court. Ming Yue v. Coos Bay R. \& E. Rr. \& Nav. Co., 24 Ore. 392, 33 Pac. 641 (1893). But the present situation appears to resemble closely that in Kentucky. Brakebush v. Aasen, 126 Ore. 1, 267 Pac. 1035 (1928).

92. Ky. Codes (Carroll, 1927) Civ. prac. $§ 6$; IowA Code (1935) $\$ \S 10941-10943$; ARK. Dig. Stat. (Crawford and Moses, 1919) $\S \S 1034,1035$.

93. Kx. Codes Anv. (Carroll, 1927) Civ. prac. $\$ 8$; Iowa Code (1935) § 10944; Ank. Dic. Stat. (Crawford \& Moses 1919) § 1042. 
court. ${ }^{94}$ The defendant may have the error corrected and the case transferred to the proper docket by motion made when he answers; otherwise, he waives any objection on this score. ${ }^{95}$ The court has certain powers to order a transfer on its own motion. ${ }^{96}$ If the action was properly begun as an ordinary one, either party may have it transferred to the equity docket for the trial of any equitable issue; and if the case was properly begun in equity, either party may transfer it to the law docket for the trial of any issue to which there is a right of jury trial. ${ }^{07}$ There are also provisions as to the order of trial of issues in case of the transfers mentioned in the last sentence.

Under such a system none of the difficulties mentioned above appears. The issues are handled as the units for determining questions of mode of trial wherever that is necessary to preserve the historical analogy and the right to jury trial afforded by the statute is exactly coterminous with that assured by the Constitution. Thus a defendant is entitled to jury trial of legal issues raised by his counterclaim to an equitable action ${ }_{j}{ }^{93}$ and to a court trial of equitable issues raised as defense or counterclaim to an ordinary action. ${ }^{99}$ Moreover, this type of statute has an additional feature which aids greatly in solving the problems incident to a united procedure. There is inherent in it a limited but effective machinery for automatic waiver of jury trial ${ }^{100}$ which answers some of the difficulties

94. Kx. Codes Ann. (Carroll, 1927) Civ. prac. $\S 9$; ARE. Dig. Stat. (Crawford and Mioses, 1919) $\$ 1042$.

95. Kr. CODES ANv. (Carroll, 1927) Civ. prac. $\$ \S 10$ (1) \& (2), 15; Iowa Cone (1935) $\S \S 10946$ (before answer) 10949; ARK. Drc. Star. (Crawford and Mroses, 1919) § 1043; Sessoms v. Ballard, 160 Ark. 146, 254 S. W. 446 (1923).

96. Kx. Codes ANx. (Carroll, 1927) $§ 10$ (4).

97. Kx. Codes Axr. (Carroll, 1927) $\$ \S 11,12$; Iown Code (1935) $§ 10947$; Ans. DrG. Stat. (Crawford and Moses, 1919) $\$ 1044$. The Iowa and Arkansas Codes do not provide for the jury trial of legal issues in actions properly begun in equity.

98. U. S. Bldg. \& Loan Ass'n v. Day, 24 Ky. L. Rep. 129, 63 S. W. 20 (1902); Woodward v. Newcomb, 12 Ky. L. Rep. 140 (1890); cf. Reusch v. Hemmer, $236 \mathrm{Ky}$. 546, 33 S. W. (2d) 618 (1930).

99. Southern Cotton Oil Co. v. East, 134 Ark. 404, 203 S. W. 1030 (1918); Crawford County Bank v. Bolton, 87 Ark. 142, 112 S. W. 398 (190S); American Soda Fountain Co. v. Futrall, 73 Ark. 464, 84 S. W. 505 (1905); Daniel v. Garner, 71 Ark. 484, 76 S. W. 1053 (1903); Groen v. Ferris, 189 Iowa 21, 176 N. W. 213 (1920); Dille v. Longwell, 169 Iowa 686,148 N. W. 637 (1914) (where, however, no proper motion to transfer was made) ; Eller v. Newell, 159 Iowa 711, 141 N. W. 52 (1913); Van Orman v. Spafford, Clarke \& Co., 16 Iowa 186 (1S64); Hackett v. Schad, 3 Bush. 353 (Ky. 1867); Petty v. Malier, 15 B. Mon. 591 (Ky. 1855); Smith v. Moberly, 15 B. Mion. 70 (Ky. 1854). The last two cases contain an especially clear and useful statement of the technique under these statutes. There is no inquiry whatever as to whether the equitable matter will necessitate affirmative relief under the combined procedure. In many cases judgment for such affirmative relief would have done no more for defendant than a simple judgment in his favor.

100. A distinction should be noted between waiver by actual consent, non-objection and the like, on one hand and, on the other, waiver implied from the act of joining legal 
raised by the "theory of the pleadings" cases. What is meant is this: If a complaint framed as in equity and filed on the equity side of the court fails to state facts showing equitable jurisdiction, though it alleges a cause of action at law, the Kentucky Code points unambiguously to the course a defendant must follow to secure a jury trial. He must move to transfer the cause to the law docket when he answers, and if he does not, later objection will not avail him. ${ }^{101}$ It is true that the same result has been worked out under other kinds of statutes. ${ }^{102}$ But the one discussed has certain distinct advantages. It contains a clear direction which will forestall judicial worry as to possible complications anent the mode of trial, when a demurrer for "want of equity" in the complaint is filed. It makes possible a determination before the trial stage is reached of the cases in which a jury will be needed, ${ }^{103}$ a factor which should aid administrative efficiency and economy. And it precludes the losing party from asserting his jury trial right for the first time on appeal. In many respects the Kentucky Code and those like it furnish a more satisfactory statutory system for solving the mode of trial problem than any of the other codes, save one. But there are two defects. First, it reproduces the historical analogy too perfectly; and while this gives it strength for the purpose under discussion here, it results in an incomplete amalgamation of law and equity for other purposes. ${ }^{104}$ The old distinctions are perpetuated

and equitable claims, or of injecting legal issues in a suit theretofore equitable. Waiver by consent may be assumed to be desirable. So it is submitted, is waiver by non-objection, for it prevents a tardy raising of the point. The other kind of waiver is to be judged quite differently for the reasons set out supra.

101. Thomas v. Farley Mfg. Co., 76 Iowa 735,39 N. W. 874 (1888); Fannon v. Ball, 202 Ky. 222, 259 S. W. 73 (1924); cf. Crawford County Bank v. Bolton, 87 Ark. 142, 112 S. W. 398 (1908), where a demurrer to an equitable defense in an action at law was treated as a motion to transfer to the equity docket.

102. An excellent example of this is seen in Indianapolis No. Tr. Co. v. Brennan, 174 Ind. 1, 90 N. E. 65 (1909) ("Appellants were bound to know what were their legal rights, and properly to assert them. Their counsel in this appeal successfully raised the question that appellee ... was not, under the law, entitled to the lien which he sought to have enforced. We have no reason to presume that they were not impressed with the same view of the law when the cause was submitted for the court for trial." So their non-objection at that time resulted in waiver of the right to a jury trial.) Sce also cases cited supra note 45.

103. This is true, of course, only of cases on the equity docket, including those which could have been transferred to the, ordinary docket by timely motion but were not.

104. Legal and equitable claims and causes of action cannot be joined in any of theso states. Ark. Dic. Stat. (Crawford and Moses, 1919) § 1076; Iown CodE (1932) § 10960; Ky. CODEs ANN. (Carroll, 1927) Civ. prac. $\$ 83$; ORE. CODE ANN. (1930) $\$ \S 1-811,6-114$; Cooper v. Erickson, 213 Iowa 448, 239 N. W. 87 (1931); Smith v. Waterloo, C. F. \& N. Rr. Co., 191 Iowa 668, 182 N. W. 890 (1921); Newsan, Ky. Pr., Pr. \& F. (3d Ed., 1916) $\S 370$. Cf. also Green v. Ferris, 189 Iowa 21,176 N. W. 213 (1920), where two actions were necessary under the Iowa code in order that an equitable defense be interposcd to an action of replevin.

In Arkansas there are two parallel systems of courts, and in some Kentucky counties 
by the constitutional guaranty of jury trial; but they need not be in other connections. Second, there is no provision for waiver of jury trial in cases properly on the ordinary docket except by affirmative action of the parties which may be delayed until the very day of the trial.

\section{The Connecticut provision}

The Connecticut Code is one of the most recent in the country, so that its framers had unusual opportunity to profit by the experience in other states and in England..$^{105}$ As a consequence they devised a machinery for regulating the mode of trial which appears to have the advantages of the Kentucky procedure without sharing its shortcomings. The principal statute provides:

"Jury docket and jury trials. In the superior court, any court of common pleas and any city court, a docket shall be kept of all cases, and in such docket immediately following the names of the parties and their attorneys in all jury cases shall be entered the word 'jury.' The following-named classes of cases shall be entered in the docket as jury cases, upon the written request of either party made to the clerk within thirty days after the return day: Appeals from probate involving the validity of a will or paper purporting to be such, appeals from the doings of commissioners on insolvent estates, and, except as hereinafter provided, civil actions involving such an issue of fact as, prior to January 1, 1880, would not present a question properly cognizable in equity. When, in any of the above-named cases, an issue of fact is joined, the case may, within ten days after such issue of fact is joined, be entered in the docket as a jury case upon the request of either party made to the clerk; and any such case may at any time be entered in the docket as a jury case by the clerk, upon written consent of all parties or by order of court. All issues of fact in any such case shall be tried by the jury, provided the issues agreed by the parties to be tried by the court may be so tried. All cases not entered in the docket as jury cases under the foregoing provisions, including actions wherein the plaintiff sues for a debt due by book to balance book accounts, actions wherein an account is demanded and judgment rendered that the defendant shall account, writs of habeas corpus, prohibition and ne exeat, complaints for divorce and all other special statutory proceedings which, prior to January 1,1880 , were not triable by jury, shall be entered on the docket as court cases, and shall, with all issues of law and issues of fact, other than those hereinbefore specified, which may be joined in actions entered on the docket as jury cases, be disposed of as court cases." 100

Under this statute, any case which presents an issue constitutionally triable by a jury will be placed on the docket as a jury case upon timely affirmative demand by either party. There is no constructive waiver of the right to jury trial of legal issues merely because they are mingled with equitable

two divisions of the circuit court. See Arr. Const. art. VI $\S 15$ (1874); Anr. Drc. Srat. (Crawford \& Moses, 1919) §§ 21S6, 2188; Ky. Stat. (Carroll, 1930) $§ 1020$.

105. It was adopted in 1879. For the dates of the various codes, see Crans, Code Pleading (1928) 19, 20.

106. Conn. Gen. Stat. (1930) $§ 5624$. 
ones in the way made possible by the united procedure. ${ }^{107}$ But if a cause is not claimed for this docket within the time set by this provision, right to jury trial is waived except in two situations to be noted later. Where the case is placed on the jury docket the court will try as a chancellor such matters therein as before 1880 were within the jurisdiction of a court of equity whether directly or as incident to other matters before it. ${ }^{108}$

These provisions seem admirably suited to accommodate the code action to the Constitution, and they do so by adopting its own test-the historical test. Yet they yield to history no more than they must, for law and equity are as fully blended in Connecticut as in any state. Even the terms of the old distinctions have little currency there, actions being commonly known as "jury cases" and "court cases." Two situations are singled out for special treatment under these rules and statutes: After an amendment to the complaint, defendant is given another opportunity to claim a jury trial; ${ }^{109}$ and he is also given that opportunity where plaintiff had alleged grounds for equitable relief, but shows only a legal cause of action at the trial. ${ }^{110}$ The first seems but a fair accompaniment to the automatic waiver provision in section 5624.111 The second is that, and more. It is incompatible with a dismissal of plaintiff's action simply because he has alleged

107. This would seem to be a necessary consequence of $\S 5624$, since such a caso would, by hypothesis, contain an issue not properly cognizable in equity before tho codo. The reasoning in the Cogswell Case, 105 N. Y. 319, 11 N. E. 518 (1887), simply could not be logically indulged in under the Connecticut provision. Nor is it. Roy v. Moore, 85 Conn. 159, 82 At1. 233 (1912); Nowski v. Siedlecki, 83 Conn. 109, 75 At1. 135 (1910).

In this connection, $\$ 5626$ should be considered. It provides that in a case properly on the jury docket no determination of equitable issues shall prevent a jury trial of a claim for damages. The purpose of this section is a little hard to find. Apparently, it does not give any right to a jury trial of the matter of damages where equity would have disposed of it as incidental to other matter before it. See Malken v. Hemming Bros., 82 Conn, 293, 73 Atl. 752 (1909) (not mentioning statute); CoNN. Pr. BK. (1934) \& 39. It may have been designed to prevent the kind of constructive waiver dealt with in the text, and has been given substantially that effect. Lewisohn v. Stoddard, 78 Conn. 575, 595, 63 Atl. 621 (1906). If that is its purpose it is badly drawn, since it does not cover all legal issues but only those incident to a claim for damages. And it is quite unnecessary as is shown by Roy v. Moore, supra, which did not mention the statute and places its result entircly upon deductions from $\& 5624$ and its necessary implications.

108. Roy v. Moore, 85 Conn. 159, 82 Atl. 233 (1912); Bisnovich v. British American Assurance Co., 100 Conn. 240, 123 Atl. 339 (1924); Conv. PR. BK. (1934) \& 39.

109. Conn. Gen. Stat. (1930) $§ 5550$. But an immaterial amendment does not afford such an opportunity. Atta v. Cutner, 95 Conn. 576, 111 Atl. 847 (1920).

110. Cons. PR. Br. (1934) $\S 40$ provides: "In a complaint demanding specific equitablo relief and damages as incident thereto (as for the reformation of a policy of insurance and the payment of a loss under the same as reformed), if the plaintiff fails to make out a case for specific relief, the defendant shall have a reasonable opportunity to have the claim for damages tried to the jury."

111. Cf. Frugate v. Walker, 204 Ky. 767, 265 S. W. 331 (1924), where the court allowed an amendment changing a case from an ordinary one to an equitable one, and transferred it at that time to the equity docket. 
but failed to show facts calling for equitable relief, provided only he proves some cause of action consistent with his complaint. ${ }^{112}$ This is so because the rule clearly tells the court how to act in such a case, and the action prescribed saves the plaintiff his case and the defendant his jury trial. Some courts have evolved just such a solution without direction by rule or statute; ${ }^{113}$ but this result may scarcely be counted on with assurance.

In one respect, however, the Connecticut provisions seem unduly to emphasize mere form. That is in the importance they attach to the claim for relief. ${ }^{114}$ But this is hardly an inherent part of the scheme. If it should be omitted from the Supreme Court rules, the federal courts will no doubt follow the generally prevailing method of determining the nature of the issues from the facts alleged in the pleadings, ${ }^{110}$ except in cases where the same facts would historically have entitled plaintiff to choose his forum by claiming one or the other kind of remedy at his option. ${ }^{110}$

\section{The order of trial of issues}

In a few of the codes there are rules or statutes governing the order of

112. By "consistent with his complaint" is meant consistent with the allegations of fact in his complaint. Obviously, in the case supposed recovery will be allowed, if at all, on a legal theory inconsistent with that on which the complaint was framed.

113. E.g., Lutton v. Baker, 187 Iowa 753, 174 N. W. 599 (1919) ; Greenleaf v. Eagan, 30 Minn. 316,15 N. W. 254 (1883).

114. Thus where relief different from that demanded in the complaint is sought, there must be an amendment of the demand in the complaint. Corrs. Ger. Srar. (1930) $8 f$ 5549, 5550; Conn. PR. BE. (1934) $\S \S 92,98,155$. So liberal is the attitude toward amendment of the prayer for relief that little difficulty actually results from these provisions, but since they do seem unnecessarily to stress form there is no good reason why they" should be adopted for the federal courts.

115. Mott v. First Nat. Bank, 171 Ark. 7, 283 S. W. 3 (1926); Donahue v. Mreicter, SS Cal. 121, 25 Pac. 1096 (1891); Gordon v. MIunn, 83 Kan. 242, 111 Pac. 177 (1910); Atkinson v. J. R. Crowe Coal \& M. Co., So Kan. 161, 102 Pac. 50 (1909); Indianpolis No. Tr. Co. v. Brennan, 174 Ind. 1, 90 N. E. 65 (1909); Boonville Nat. Banls v. Blaliey, 166 Ind. 427, 76 N. E. 529 (1906); McAnulty v. Peisen, 203 Iora 625, 226 N. W. 144 (1929); Lynch v. Schemmel, 176 Iowa 479, 157 N. W. 169 (1916).

116. Thus a judgment creditor, on the same showing, may be entitled cither to set aside a transfer made in fraud of him, or to have damages on account of it. Nowsly $\mathbf{v}$. Siedlecki, 83 Conn. 109, 75 Atl. 135 (1910). Similiarly, an incompetent's administrator may seek cancellation of his intestate's deed to realty or he may have possesion of the property without cancellation. Monnett v. Turpie, 132 Ind. 482, 133 Ind. 424, 32 N. E. 328 (1892). And a purchaser who has tendered the return of goods fraudulently sold him may treat this as rescission and sue for money had and received, or may acl: the court for a formal decree of rescission. Dodd v. Boles, $137 \mathrm{Kan} .600,21 \mathrm{P}$. (2d) $36 \mathrm{~A}$ (1933). These are simply examples. Not infrequently, it is suggested, the facts alleged in the complaint will entitle plaintiff to legal or equitable relief, as he chooses. He could control the mode of trial before the codes by the exercise of this option. There seems to be no reason to deprive him of such choice nov; and generally he is not. 
trial of issues where a case presents both legal and equitable aspects. ${ }^{117}$ But where the other hurdles have been overcome the courts seem scarcely at a loss in working out a satisfactory solution of this one, even without a specific direction. ${ }^{118}$ As a matter of fact what little trouble there has been seems to have resulted from attempts to give such directions by rule or statute. ${ }^{119}$ An express permission to try issues separately may call attention to the possibility though it is probably unnecessary. Little could be gained from more explicit direction.

\section{Waiver of Jury Trial}

In all the code states there are provisions for the waiver of jury trial. One was enacted as a part of the original Field Code ${ }^{120}$ which has been widely copied. ${ }^{121}$ It provided for waiver by written consent of the parties filed with the clerk; by oral consent in open court entered in the minutes, or by failure to appear at the trial. Under a law like this, it is obvious that in the vast majority of cases there is no way of telling before trial whether there is going to be a waiver of the constitutional right. In fact, it is not perfectly clear in all states whether a party waives it by going to trial before the court alone without objection, ${ }^{122}$ though in most jurisdic-

117. Conn. Gen. Stat. (1930) $\S 5627$ provides that in all cases the court may order that one or more issues be tried before the others. Cons. Pr. BK. (1934) \& 149 provides that non-jury issues are triable first unless the court otherwise directs. In Kentucky the statute directs legal issues to be tried first if the case was properly begun as an ordinary one and there is a motion to transfer; and equitable issues to be tried first if the case was properly started in equity. Kx. Codes Aws. (Carroll, 1932) Civ. prac. $8 \S 11(3), 12$.

118. The nature of the issues will usually point clearly enough to the most practical order of trial. Frequently an equitable defence embodies matter which, if true, will end the controversy. And in such cases usually the equitable question was settled first, historically, the legal action being stayed. The solution under the codes has been almost uniformly the same. See cases supra notes $73,74,85,99$. In almost none of these cases was it necessary to reverse the trial court because of the order in which the issues were tried (except in the Kentucky cases, treated below). See, however, Penninger Lateral Co., Ltd. v. Clark, 22 Idaho 397, 126 Pac. 524 (1912), where such reversal was necessary.

On the other hand, the settling of a legal issue (e.g., title, existence of a debt, etc.) is sometimes a condition precedent to the granting of equitable relief, and this fact itsclf indicates the proper order of trial.

119. Roy v. Moore, 85 Conn. 159, 82 Atl. 233 (1912); Meek v. MeCall, 80 Ky. 371, 4 Ky. L. R. 255 (1882); Hill v. Phillips, 87 Ky. 169 (1888); Carder v. Weisengburg, $95 \mathrm{Ky} .135,23 \mathrm{~S}$. W. 964 (1893). In each case the trial court was reversed for error in order of trial of the issues. In each, also, the trial court appears to have been misled by the direction in the rule or statute. The Connecticut rule is only permissive.

120. There has been added to the original section, in New York, the following: "4. By moving the trial of the action, without a jury, or, if the adverse party so moves it, by failing to claim a trial by a jury, before the production of any evidence upon the trlal." This provision is not found in the other codes.

121. N. Y. Sess. Laws (1848) c. 379, § 2221.

122. Shaw v. Kent, 11 Ind. 80 (1858); Jackson v. Strong, 222 N. Y. 149, 118 N. E. 512 (1917). 
tions he is held to have done so; ${ }^{123}$ and in some, even his objection will not avail him if it was broader than his right. ${ }^{124}$ Up to this time, however, if a party does nothing, his right remains intact-waiver is accomplished only by affirmative act. Neither indifference nor inertia, but only a modicum of exertion will effect it. The administrative difficulties this may entail are great. Two cases furnish apt illustration. The action of Platt $v$. Havens was pending in Department 4 of the Superior Court for San Francisco County, California. On December 20,1895, the parties stipulated that it should be set down by the court on any day convenient to it after the 15th day of January next. The court set it for March 3, but it was not reached and went over until March 16. On that day it was not reached and while reassignment was being discussed defendant first claimed a jury. It has been notorious for years that Department 4 heard nothing but court cases, and the demand was denied. The Supreme Court reversed this ruling because there had been no waiver as prescribed by the Code. ${ }^{125}$ The case of Farwell $v$. Murray was set for trial at $10 \mathrm{a} . \mathrm{m}$. on August 22. When it was reached, defendant was granted a continuance until two o'clock the same day, at which time he first claimed a jury. A denial of his request was held error. ${ }^{120}$ Such events disrupt orderly procedure, and for decades the Superior Court in California attempted to prevent them by rules which required parties to claim a jury when the case was called to be set for trial on pain of waiving their rights to one. These rules, however, met repeated rebuffs from the Supreme Court. ${ }^{127}$ That body finally came to the aid of the Superior Court in 1901 and enacted the substance of its attempted rules. ${ }^{129}$

Several other codes required a party to do an affirmative act to secure a jury trial. Some provide for an oral claim, some for a written claim, some have alternative provisions. ${ }^{129}$ Payment of a jury fee is frequently

123. Pollock v. Cantlin, 253 III. App. 229 (1929); Goodwine v. Hedrick, 24 Ind. 121 (1865); Indianapolis No. Tr. Co. v. Brennan, 174 Ind. 1, 90 N. E. 65 (1909) (overruling Shaw v. Kent, note 122); Holland Piano MIf. Co. v. Smith, 155 Minn. 6, 192 N. W. 355 (1923); Bratschi v. Loesch, 330 Mo. 697, 51 S. W. (2d) 69 (1932).

124. Holland Piano Mffg. Co. v. Smith, 155 Minn. 6, 192 N. W. 355 (1923).

125. Platt v. Havens, 119 Cal. 244, 51 Pac. 342 (1897).

126. Farwell v. Murray, $104 \mathrm{Cal} .464,38$ Pac. 199 (1S94).

127. See supra note 20. Cf. Naphtaly v. Rovegno, 130 Cal. 639, 63 Pac. 66 (1900) in which the failure to pay a jury fee was relied upon to support a ruling by the Superior Court, based on the violation of the kind of rule here mentioned.

128. CaI. Sess. Laws (1901) p. 146.

129. ARTz. REv. CODE ANN. (Struckmeyer, 1928) $\$ 3802$ provides that on such doys as may be fixed by the court it shall set all causes at issue for trial; that a jury may be demanded by either party in writing before such day, or orally in open court at the time of setting. If there is no such demand the right is waived and the case triable to the court unless it shall otherwise order. CAx. Code Crv. Proc. (Deering, 1931) \& 631, par. 4, provides for waiver by failing to announce that a jury is required, at the time the cause is first set upon the trial calendar if it be set upon notice or stipulation. The Connecticut 
provision is set out above. In Georgia various Municipal Court acts provide for a Jury only upon filing a written claim on or before the calling of the docket at the term to which the cause is made returnable. Sutton v. Gunn, 86 Ga. 652, 12 S. E. 979 (1891); Heard v. Kennedy, 116 Ga. 36, 42 S. E. 509 (1902); Terry v. Drew, 143 Ga. 473, 85 S. E. 314 (1915). HAWAII REv. L. (1935) $§ 4101$ provides for waiver unless a written jury claim is filed "within ten days after the case is at issue." ILL. Stat. Axs. (Smith-Hurd, 1935) c. 110 , par. 192, \& 64 provides for waiver by plaintiff unless he files a written demand when suit is begun, by defendant unless he files it when be appears. Iown Cope (1931) $\S 10724$ provides that in the Superior Courts for certain counties, when causes are asslgned for trial any party may make demand for a jury or the same shall be waived. $\$ 10730$ provides that such jury shall be of 6 , unless 12 are specifically demanded. These provisions do not apply to the District Court. Mass. Gen. Laws (1932) c. 231, $\$ 60$ provides that no case shall be put upon the jury list unless a party, before issue joined, or within 10 days after time for filing plea or answer, or within 10 days after the answer or plea has been filed (by consent or permission) or within such time after the parties are at issue as the court may by general or special order direct, file a notice that he desires a jury trial. Rule 44 of the Superior Court Rules provides for jury waiver unless a party files such notice not later than 10 days after time for filing answer or plea, or after its actual filing, where made later by consent or leave of court. Mrce. Cosp. Laws (1929) $\S 14263$ provides for trial by the court unless a jury is demanded as provided by rule of court. MicrnonN Court Rules, ANn. (Searle, 1930). Rule 33 provides that the demand must be in writing and filed with the clerk and served upon the adverse party "within fifteen days after the issue is joined in the cause." N. M. Star. Ars. (Courtright, 1929) \&105-814 provides for waiver unless a case is claimed for the jury upon the calling of ready cases at the opening of the term. The Utah Constitution declares that a jury in civil cases is waived unless demanded. Urä CoNst. art. I, $\&$ 10. The statute provides that demand must be made in writing before the case is called to be set for trial, or orally at the time of such calling. Utä Rev. Stat. Ann. (1933) § 104-23-6. Wyo. Rev. Stat. Ann. (Courtright, 1931) $\$ 89-1320$ provides for waiver unless defendant demands a jury in writlng when he answers, or the plaintiff at the time for reply. This state formerly had a provision like that in California. Wro. Cosrp. Star. (1910) $\S 4514$. The change was made by Laws 1915, c. 66, \& 1. WaSr. Rev. Stat. ANv. (Remington, 1932) $\& 316$ requires a party who desires a jury to file with the clerk and serve on his adversary a statement of his election of jury trial at or prior to the time the case is called to be set for trlal.

130. CAx. Code Crv. Pro. (Deering, 1931) \& 631, par. 5, provides for waiver by failing to deposit with the clerk, 10 days before the date set for trial, jury fecs for one day. Paragraph 6 provides for waiver by failing to deposit, promptly after the impanelment of the jury the accrued mileage and transportation allowances to the jurors. Paragraph 7 provides for waiver by failing to deposit at the beginning of the second and each succeeding day's session a day's jury fee and mileage or transportation allowanco. The expense of the jury was first put upon the litigants in California by SrsT. 1869-1870, c. CXLIV, $\S 28$ (p. 176). The adoption of the Code did not change this. Carpenter v. Jones, 121 Cal. 362, 53 Pac. 842 (1898). The present form of the jury waiver statuto was substantially adopted in 1917 . STAr. 1917 , c. 569, p. 788 . In Connecticut a jury fee of $\$ 10$ must accompany the claim for jury trial. Cons. GEN. STAT. (1930) \& 2254.

In Cook County, Ilinois, there is a jury fee of $\$ 8$ payable at the time now set for the jury demand. Ill. Rev. Stat. AnN. (Smith-Hurd, 1933), c. 53, \& 51. This was first provided by Laws 1929, pp. 468, 9, but a jury fee had theretofore been required in Municipal Courts. See Williams v. Gottschalk, 231 Ill. 175, 83 N. E. 141 (1907). In Iowa a jury fee of $\$ 10$ is taxable as costs in all civil cases, the sum to be paid to the 
the calling of a case to set it for trial, or within a certain time of the closing of issues. ${ }^{129}$

Provisions for automatic waiver in one of these ways have been increasingly adopted, especially where calendars are crowded, a fact which testifies to the greater efficiency they make possible. ${ }^{131}$ But this administrative aspect is not their only one. Such statutes result in eliminating any question as to mode of trial from all jury-waived cases at an early stage in their pendency. Under the New York provision, even where none of the parties to a suit really wants it tried to a jury, each may without risk of loss allow the problem of mode of trial to remain in it, unsolved, with the hope that he may win some tactical advantage by a belated assertion of his right, or perhaps secure a reversal because it has not been given him. Further, automatic waiver provides-somewhat in the manner of the Kentucky Code-a satisfactory method for handling those actions which are framed on an equitable theory while the facts alleged call for only legal relief.

Various mechanical problems and difficulties arise under provisions for the automatic waiver of jury trial. What, for instance, is the best point of time at which to require jury claim? The assignment of the case for trial was chosen by the California Code..$^{100}$ It seems that assignments are generally there made once a month on a day prescribed by rule. ${ }^{132}$ So there would result, a substantial amount of advance notice to courts, clerks and sheriffs of the need for a jury. The calendar and

county treasurer. Iowa CoDe (1935) $\S 11629$. In the Superior Courts a jury of 12 may be had only by paying the entire expense occasioned by demanding more than six. Iowa Code (1935) $\S 10731$. Mircr. Conrp. LAws (1929) $\$ 14273$ provides that when a jury" trial is demanded the party making the demand shall pay a fee of $\$ 3$ before the impanclling of the jury is begun. This sum is taxable as costs. In Minnesota there was for years a statute requiring plaintiff to pay a $\$ 3$ fee before the jury was sworn. AInn. GEz. Strir. (1867) c. 66, § 206; MINN. REv. STAT. (1905) § 4170. This was repealed by Laws, 1913, c. 217. A jury fee is still required in Municipal courts. The Nev Mexico provicion is not unlike that of California. N. MI. STat. Aws. (Courtright, 1929) $\S 105-\$ 15$ (\$36). In Utah a fee of $\$ 5$ must accompany the jury claim. UT:H REv. SrAT. Arzi. (1933) $\$ 104-23-6$. In Wyoming there is a similar requirement, but the fee is \$12. Wro. REv. Star. Ariz. (Courtright, 1931) § 89-1320. WASH. REv. STAT. Ams. (Remington, 1932) $\S 316$ require a $\$ 12$ jury fee to be paid when the jury claim is filed. $\S 317$ malies this an item of taxable costs.

131. The history of the various California provisions has been given. The jury fee requirement in Cook County, nlinois, is of recent origin. See supro note 90. The Mllinois automatic waiver provision was ushered in by the new Practice Act in 1933; formerly express waiver was required. Irc. Rev. Star. Amz. (Smith-Hurd, 1921), c. 110, 8$\}$ 60-61. New York requires an affirmative demand and a fee of $\$ 12$ before a jury can be had in New York and Bronx counties. Laws 1927, c. 696. And affirmative demand and a fee of $\$ 5$ is also necessary in Hamilton and Cuyahoga counties. Orno Ger. Code (Page, 1931) $\S \S 11466,11467$. See Tuttle, Reforms in Federal Procedure (1928) 14 A. B. A. J. 37, 41.

132. Cal. Superior Court Rules, Rules V and VI provide for assignments to be made on the first Monday of the month for the period of a month to begin on the third Monday. 
other administrative problems might be largely solved. If such a scheme should be adopted there should be express provision covering the following points in order to prevent uncertainty: (1) Whether claim must be made on or before the time the case is first reached to be assigned, ${ }_{1}^{13 a}$ and (2) when and how a jury claim should be made where the assignment is without notice or otherwise irregular. ${ }^{134}$ The second provision is apt to be cumbersome and productive of some trouble. ${ }^{136}$ There is need for elasticity and discretion in handling assignments which, perhaps, makes the time of their occurrence but a poor mark to serve as a definite boundary. Other statutes fix upon various other steps in the progress of a case to limit the period during which the right to a jury trial may be claimed. Illinois has chosen the earliest one-commencement of suit, for the plaintiff; for the defendant, entry of his appearance. ${ }^{120}$ This provision has the advantage of being simple and definite. And it segregates at the threshold those actions which may present a question as to the mode of their trial. On the other hand it requires the claim to be made before the pleadings are closed and so, often, before it is clear what all the issues in the case will be. ${ }^{136}$ In some states a jury must be claimed within a certain number of days after the closing of issue. ${ }^{\mathbf{1 2 0}}$ This seems the most satisfactory time of all for it will generally be long before the case is assigned for trial, yet the parties are permitted to make their choice with all the facts before them. Moreover, it is usually easy enough to tell when the issues are closed even though there may be occasional doubt as to whether a reply is proper or necessary. ${ }^{137}$ If

133. The California act so provides. CAL. CoDE Crv. Proc. (Deering, 1931) $\$ 631$ (4). See also Mindlin v. Jones, 26 Ariz. 401, 226 Pac. 209 (1924) which sets out a similar provision in the rules of the Superior Court for Gila county, which have, however, been superseded by the Uniform Rules of Practice promulgated by the Supreme Court. Brown v. Haymore, 32 P. (2d) 1027 (Ariz. 1934).

134. The Arizona statute has no such provision. ARIz. REv. CODE ANv. (Struckmeyer, 1928) \& 3802. Nor do the Uniform Rules of Practice supply this omission. So where the record fails to show that a case was assigned at the regular calendar call, a jury may be claimed as late as the day set for trial. Brown v. Haymore, 32 Pac. (2d) 1027 (Arlz. 1934). To similar effect is Smith v. Redmond, 141 Iowa 105, 119 N. W. 27 (1909). The California Act specifically provides for irregular assignments.

135. It necessitates, for example, a showing in the record of whether the case was assigned on regular calendar call, and if not, whether it was set on stipulation, or without any notice. If without notice, it must appear when notification of the assignment was received. And if the record does not affirmatively show waiver in strict accordance with the statute, the benefit of all this machinery is lost. White v. Kretz Bros., 122 Cal. App. 197, 10 P. (2d) 198 (1932).

136. It fails, for instance, to take into account a case where the plaintiff tenders equitable issues only but is met by a counterclaim presenting legal issucs. Apparently plaintiff must anticipate such a possibility when he commences suit, or forego jury trial of issues not yet made.

137. It is assumed that the Supreme Court will adopt the usual code rule which allows no pleading beyond a reply and requires a reply only to "new matter" contained in the 
difficulty on this score is feared, however, the filing of an answer could be made the basis of reckoning and this would often coincide with the joinder of issue. Perhaps this is as definite and readily ascertainable a point in the proceedings as any other ${ }^{138}$

The affirmative claim must usually be in writing and filed with the clerk where it is required at all. But claims made on the call of the calendar, under the California system, are oral. ${ }^{120}$ Of course they are in open court and so are to be entered on the minutes. Either method would seem to provide an adequate and unequivocal record of the claim, and of the time it is made. ${ }^{139}$

Another problem which has arisen in connection with both kinds of automatic waiver provisions concerns the extent to which a party may rely on his adversary's claim for jury trial. Mlinois has expressly taken care of this situation. ${ }^{140}$ In other states the solution of the question has been left to the courts, and is not uniform. There are three ways of handling it: (1) Each party could be deemed to have waived jury trial unless he has filed claim therefor; ; $^{1 * 1}$ (2) a party might be allowed to rely on his adversary's claim unless and until it is withdrawn, but required to file his own claim upon such withdrawal; ${ }^{122}$ or (3) he could be permitted to rely on such adversary's claim as sealing the right to jury trial except on affirmative consent of all parties. ${ }^{143}$ Unless the rules limit the choice of method, uncertainty and lack of uniformity may result-though to be sure the difficulty may not often be presented. If it is desired to specify the solution, the problem of selecting one raises for the most part only considerations of administrative expediency.

answer. Where pleadings are proper until an issue is closed, as in Connecticut, even the occasional doubt would be removed.

138. The Wyoming act chooses the filing of an answer and the time for reply for defendant and plaintiff respectively. Nothing is said, however, about the ase where there is more than one defendant and more than one answer, consequently more than one time for reply.

139. But where a waiver is claimed, a greater burden is sometimes put upon the record by the California type of provision than by the other. See notes 134 and 135 , supro.

140. Ilt. Rev. Stat. Ans. (Smith-Hurd, 1935) c. 110, par. 192, $\$ 188$.

141. Dunham v. Reichlin, 217 Cal. 289, 18 P. (2d) 664 (1933).

142. Stukey v. Stephens, 37 Ariz. 514, 295 Pac. 973 (1931). This is what the Illinois statute provides.

143. First Tr. Co. of Hilo v. Cabrinhs, 24 Haw. 777 (1919). In her Uniform Rules of Practice, Arizona has now adopted this solution. See Rule III (2), cited in Brown v. Haymore, 32 P. (2d) 1027, 1029 (Ariz. 1933). 